DOI https://doi.org/10.30525/978-9934-26-117-6-11

\title{
ПЕРШІ ДРУКОВАНІ ШКОЛИ ГРИ НА БАНДУРІ У ВІДДІЛІ МУЗИЧНИХ ФОНДІВ НАЦІОНАЛЬНОЇ БІБЛІОТЕКИ УКРАЇНИ ІМЕНІ В. І. ВЕРНАДСЬКОГО
}

\author{
Макогон О. А. \\ молодший науковий співробітник відділу музичних фондів \\ Інститут книгознавства Національної бібліотеки України \\ імені В. І. Вернадського \\ м. Київ, Украӥна
}

Відділ музичних фондів Національної бібліотеки України ім. В. І. Вернадського (далі НБУВ) $€$ спеціалізованим науковим підрозділом НБУВ у складі Інституту книгознавства - найбільшим та найбагатшим нотосховищем нашої держави. Поміж численних нотних видань, рукописів, книг, періодики тощо, хронологічні рамки яких охоплюють XVII - XXI століття, значне місце займають видання, в яких висвітлюється історія та розвиток кобзарського мистецтва.

Бандура та кобза - національні інструменти, які без перебільшення можна вважати візитною карткою музичної культури українців. Адже саме кобзарі були носіями найважливіших факторів української минувшини. У їхніх думах, піснях, баладах упродовж століть оспівувалася краса та велич українського народу, його героїзм і прагнення до волі.

Інтерес до бандурного мистецтва ніколи не втратить своєї актуальності як в освітньо-виховному процесі, так й у професійному виконавстві, а це, як правило, вимагає наявності цікавого нотного матеріалу.

Значну частину фонду музичного відділу НБУВ складають видання, що пов'язані з кобзарським мистецтвом. Це нотодруки, у яких вміщено репертуарний матеріал для кобзи та бандури, а також документи, що висвітлюють правила навчання гри на цих інструментах.

Особливу цінність серед нотодруків та підручників складають ті, які належать авторству визначних українських митців, а саме Миколі Лисенку, Філарету Колессі, Гнату Хоткевичу, Станіславу Людкевичу, Михайлу Домонтовичу, Василю Шевченку, Василю Овчиннікову та іншим.

До числа перших музикантів, котрі почали створювати репертуар для кобзи та бандури, закладаючи в їх основу навчання майстерності бандурної гри, належить Гнат Хоткевич. 1909 року, у Львові було опубліковано його «Підручник гри на бандурі», що репрезентує 
різноманітну методику та техніку опанування гри на цьому інструменті [5].

У відділі музичних фондів НБУВ зберігається перша частина цього підручника, а також друга, що була видана 1929 року в Державному видавництві України [4]. У тому ж видавництві 1930 року вийшов оновлений та удосконалений автором посібник під такою ж назвою [6]. У ньому автор подає різні види звуковидобування на бандурі, більш різноманітні та удосконалені. Окрім педагогічної роботи Г. Хоткевич займався активною просвітницькою, письменницькою та композиторською діяльністю. 31896 року виступав з концертами як бандурист. У 1910 році, під керівництвом Г. Хоткевича був створений гуцульський музично-драматичний театр, 3 яким митець гастролював у Харкові, Одесі а також Польщі, Буковині та Галичині. Концерти Г. Хоткевича були цікаві тим, що окрім музики вони включали повчальні розповіді про бандуру та особливості методики гри. У відділі музичних фондів НБУВ зберігається й композиторський доробок митця, що складається з обробок народних пісень та оригінальних творів для бандури, а також солоспівів, творів для хору на слова різних поетів.

Окрім праць Г. Хоткевича у фондах музичного відділу зберігаються й інші підручники, що висвітлюють історію кобзарського мистецтва, i водночас $є$ методичними посібниками засвоєння майстерності гри на бандурі. Це праці Михайла Домонтовича «Самонавчатель до гри на кобзі або бандурі» [1; 2], видані в Одесі 1913 р. - перша частина, та 1914 р. - друга, у друкарні Юхима Фесенка. Майже одночасно у 1913-1914 роках Московською друкарнею В.Гроссе, бандурист Василь Шевченко опублікував підручник «Школа для бандури на 27 струн» [7] у трьох частинах 3 малюнками та поясненнями. На жаль, не знайдено відомостей про місце зберігання другої частини цього підручника, а ось третя частина [8], яка також знаходиться у відділі музичних фондів НБУВ, побудована автором на зразок першої, однак зі зменшеним вмістом вправ та пісень.

Орієнтовно у 1910-1917 роках, точний рік публікації цієї праці поки що встановити не вдалося Василь Овчинніков - вихованець Василя Шевченка також видав «Самовчитель гри на бандурі (кобзі)», який був виданий у Московській друкарні В. Гроссе [3].

Сьогодні перші підручники бандурної гри не втрачають своєї актуальності й цінності. Методичні та технічні прийоми Г. Хоткевича, М. Домонтовича, В. Шевченка, В. Овчиннікова широко застосовуються у роботі сучасних педагогів, музикознавців та виконавців.

Окрім підручників, що стосуються навчання та методики гри на кобзі й бандурі, відділ музичних фондів НБУВ багатий великим 
репертуарним матеріалом для кобзарів та бандуристів, хронологічні рамки нотної продукції охоплюють кінець XIX - XXI ст. В нотних збірниках репрезентовано різножанрові твори композиторів України та зарубіжжя, таких як Гнат Хоткевич, Сергій Баштан, Андрій Бобир, Володимир Войт, Андрій Омельченко, Анатолій Коломієць, Петро Чухрай та інші.

Величезний внесок у розвиток кобзарського мистецтва зробили такі відомі кобзарі як Остап Вересай, Михайло Кравченко, Іван КучугураКучеренко, Петро Кулибаба, Федір Кушнерик, Сгор Мовчан, Василь Нечепа, Степан Пасюга та інші. Це були митці наділені великими музичними талантами. Твори, які вони виконували користувачі НБУВ також можуть знайти у відділі музичних фондів.

Нині фонди бібліотеки поповнюються новими надходженнями, які стосуються кобзарського мистецтва, як нотними виданнями, так і методичними посібниками. Уся музична література опрацьовується бібліографічно, вводиться до електронної бази даних відділу. I в недалекому майбутньому відвідувачі бібліотеки зможуть скористатися нею у відкритому доступі.

\section{Література:}

1. Домонтович М. О. Самонавчатель до гри на кобзі або бандурі. Ч. 1 : Діло : Одеса, 1913. 17 с.

2. Домонтович М. О. Самонавчатель до гри на кобзі або бандурі. Пісні з нотами для співу й виконання на кобзі. Ч. II : Діло, Одеса, 1914. $50 \mathrm{c}$.

3. Овчинніков В. Самовчитель гри на бандурі (кобзі) : Москва, [1910-1917]. 15 c.

4. Хоткевич Г. М. Підручник гри на бандурі. Ч. 2. Вправи. Вип. 2 : [Харків], 1929. 63 с.

5. Хоткевич Г. М .Підручник гри на бандурі : Львів, 1909. 20 с.

6. Хоткевич Г. М. Підручник гри на бандурі. Ч. 1: Харків, 1930. $20 \mathrm{c}$.

7. Шевченко В. Школа для бандури. Ч. 1 : Москва, 1913. 11 с.

8. Шевченко В. Школа для бандури . Ч. 3 : Москва, 1914. 15 с. 